\title{
Antioxidative activities of ethanolic extracts of Du-zhong (Eucommia ulmoides Oliver) leaf and bark
}

\author{
Dong Chung Kim ${ }^{1} \mathbb{C}$ \\ 두충나무(Eucommia ulmoides Oliver) 잎과 껍질의 에탄올 추출물의 \\ 항산화 활성
}

김 동 청1

Received: 25 August 2020 / Accepted: 7 September 2020 / Published Online: 30 September 2020

(C) The Korean Society for Applied Biological Chemistry 2020

\begin{abstract}
Antioxidative activities of $50 \%$ ethanolic extracts from Du-zhong (Eucommia ulmoides Oliver) leaf and bark were investigated. Yields of the leaf and bark extract were $8.1 \pm 0.31$ and $17.4 \pm 0.89 \%$, respectively. Polyphenol contents of the leaf and bark extract were $64.1 \pm 3.35$ and $42.4 \pm 2.38 \mu$ g gallic acid equivalents/ $\mathrm{mg}$, respectively. Flavonoid contents of the leaf and bark extract were $24.0 \pm 3.15$ and $36.7 \pm 3.18 \mu \mathrm{g}$ quercetin equivalents $/ \mathrm{mg}$, respectively. As concentration of the leaf and bark extract increased, their antioxidative activities proportionally increased. $\mathrm{EC}_{50}$ values of the leaf and bark extract for cation radical scavenging were $560.6 \pm 17.65$ and $1,357.4 \pm 8.45 \mu \mathrm{g} / \mathrm{mL}$, respectively. $\mathrm{EC}_{50}$ values of the leaf and bark extract for free radical scavenging were $574.2 \pm 14.70$ and $2,103.1 \pm 108.59 \mu \mathrm{g} / \mathrm{mL}$, respectively. $\mathrm{EC}_{50}$ values of the leaf and bark extract for ferric reducing antioxidant power were $319.9 \pm 13.42$ and $705.9 \pm 26.08 \mu \mathrm{g} / \mathrm{mL}$, respectively. $\mathrm{EC}_{50}$ values of the leaf and bark extract for nitrite scavenging were $2,329.2 \pm 35.11$ and $5,467.6 \pm 243.92 \mu \mathrm{g} / \mathrm{mL}$, respectively. In the presence of $74.8 \mu \mathrm{g} / \mathrm{mL}$ of the leaf extract and $177.2 \mu \mathrm{g} / \mathrm{mL}$ of the bark extract, linoleic acid peroxidation was inhibited by 70.0 and
\end{abstract}

Dong Chung Kim $(\bowtie)$

E-mail:kimdc@chungwoon.ac.kr

${ }^{1}$ Department of Chemical Engineering, Chungwoon University, Incheon 22100, Republic of Korea

This is an Open Access article distributed under the terms of the Creative Commons Attribution Non-Commercial License (http://creativecommons. org/licenses/by-nc/3.0/) which permits unrestricted non-commercial use, distribution, and reproduction in any medium, provided the original work is properly cited.
$79.1 \%$, respectively. The Du-zhong leaf extract possessed higher antioxidative activities than its bark extract.

Keywords Antioxidative activities · Du-zhong (Eucommia ulmoides Oliver) $\cdot$ Ethanolic extract $\cdot$ Flavonoid $\cdot$ Polyphenol

\section{서 론}

두충나무(Du-zhong, Eucommia ulmoides Oliver)의 잎과 껍질은 뛰어난 약리효과를 가지고 있어 동아시아 지역에서 천연 생약 재로 널리 사용되어 왔다[1]. 두충나무의 잎에는 폴리페놀, 플 라보노이드 및 triterpenoid의 생리활성 물질이 다량 함유되어 있 고[2], 두충나무 잎의 물 추출물은 우수한 항산화 활성을 가지 는 것으로 알려져 있다[3]. 두충나무 잎에 들어있는 폴리페놀 화합물로는 pyrogallol, ferulic acid, protocatechuic acid, coumaric acid 및 chlorogenic acid 등이 있고, 플라보노이드 화합물로는 quercetin, rutin, kaempherol 및 astragarin 등이 보고되었다[4]. 두충나무 잎의 물 추출물은 산화적 스트레스에 의해 야기되는 $\mathrm{DNA}$ 손상 및 지질 과산화를 억제하였고[5], 산화적 위 점막 손 상을 방지하는 효과도 가지고 있었다[6]. 두충나무 잎 추출물의 $30 \%$ 메탄올 분획은 고지방 식이를 한 쥐에서 체중과 백색지방 을 감소시키는 항비만 효과와 함께 혈중 중성지방과 콜레스테 롤 수치도 현저히 감소시켰는데[7], 이는 간에서의 지방산과 콜 레스테롤 생합성을 저해함으로써 항고지혈증 효과를 나타내는 것으로 확인되었다[8]. 두충나무 잎 추출물은 제2형 당뇨 유발 동물실험에서 간, 신장, 적혈구의 과산화수소와 지질 과산화물 을 현저히 낮춤으로써 당뇨 관리에 도움을 주는 항산화 효과를 
나타내었다[9]. 또한 두충나무 잎의 아세톤 추출물은 in vitro에 서 암세포 증식억제와 항산화 효과를 나타내었다[10].

두충나무 껍질의 물 추출물은 cyclooxygenase-2의 활성을 억 제함으로써 항염증 효과를 보여주었고[11], 또한 껍질의 메탄올 추출물은 여드름균(Propionibacterium acnes)의 생육을 저해하는 항균 활성을 가지고 있었다[12]. 두충나무 껍질의 $60 \%$ 에탄올 추출물은 동물실험에서 에스트로겐 결핍에 의해 야기되는 골다 공증을 억제하였고[13], 껍질의 $25 \%$ 에탄올 추출물은 동물실험 에서 사염화탄소에 의해 유도되는 간 손상을 억제하는데 효과 가 있었다[14]. 두충나무 껍질의 물 추출물은 동물실험에서 신 경보호 효과가 있었고[15], 임상시험에서 혈압 감소 및 베타 차 단제(beta-adrenergic blocker)로서의 활성을 가지고 있었다[16]. 또한 두충나무 껍질에서 분리된 ignoid와 iridoid 유도체들은 면 역을 증진시키는 항보체 활성을 가지고 있었다[17].

두충나무 잎과 껍질의 추출물 모두 지질과산화 억제, 활성산 소종 소거, 생체 분자의 산화 억제 등의 항산화 효과를 가지고 있고, 특히 잎이 껍질보다 항산화 효과가 다소 높다는 연구 결 과가 알려져 있다 $[5,18,19]$. 또한 두충나무 잎, 껍질, 꽃, 열매를 물로 추출하여 유리라디칼 소거능 등을 비교하였으나[3], 추출 용매에 따른 두충나무 잎과 껍질 추출물의 다양한 항산화 활성 에 대한 체계적인 비교 연구는 부족한 실정이다. 따라서 본 연 구에서는 두충나무의 잎과 껍질을 식품산업에서 추출용매로 사 용 가능한 물과 에탄올의 혼합용액으로 추출한 후 폴리페놀 및 플라보노이드 함량, 유리라디칼 및 양이온라디칼 소거활성, 환 원력, 아질산염 소거활성 및 지질과산화 저해활성을 종합적으로 비교함으로써 기존의 두충나무의 항산화 효과에 관한 기존의 연 구 $[5,18,19]$ 를 보완함은 물론 우수한 생리활성 소재인 두충나무 의 잎과 껍질을 항산화 소재로서 용도 확대하는데 기여하고자 하였다.

\section{재료 및 방법}

\section{실험 재료 및 추출물 제조}

본 실험에서 사용된 gallic acid, quercetin, L-ascorbic acid, Folin \& Ciocalteu's phenol 시약, diethyleneglycol, 2,2'-azinobis(3-ethyl-benzothiazoline)-sulfonic acid (ABTS), potassium ferricyanide (III), 2,2-diphenyl-1-picryl-hydrazyl (DPPH), citric acid, ferric chloride, sodium nitrite, linoleic acid 및 ferrous chloride는 Sigma-Aldrich (St. Louis, MO, USA)의 제품이었고, 그 외는 1 급 이상의 시약을 사용하였다.

두충나무 잎과 껍질의 분말은 국산(Green Natural, Jindo, Korea)을 사용하였다. 두충나무 잎과 껍질 분말에 10 배 $(\mathrm{w} / \mathrm{v})$ 의 $50 \%$ (v/v) 에탄올 용액을 넣고 $40{ }^{\circ} \mathrm{C}$ 의 항온진탕조(Jeio Tech, Daejeon, Korea)에서 2시간 추출한 후 10 분 동안 원심분리 $(3,000 \times \mathrm{g})$ 하여 상등액을 얻었고 농도별로 희석하여 실험에 사 용하였다.

\section{두충나무 잎과 껍질 추출물의 총 폴리페놀 함량}

두충나무 잎과 껍질 추출물에 함유되어 있는 총 폴리페놀 함량 은 Folin과 Denis의 방법을 변형하여 측정하였다[20]. 두충나무
잎과 껍질 추출물 $0.2 \mathrm{~mL}$ 에 증류수 $0.8 \mathrm{~mL}$ 와 Folin-Ciocalteu 시약 $1.0 \mathrm{~mL}$ 를 넣어 실온에서 5 분 동안 반응시키고, $10 \%$ sodium carbonate 용액 $2.0 \mathrm{~mL}$ 를 첨가하여 1시간 놓아둔 후 $725 \mathrm{~nm}$ 에서 흡광도를 측정하였다. 총 폴리페놀의 함량은 $\mu \mathrm{g}$ gallic acid 당량(GAE)/mg-추출물로 나타내었다.

\section{두충나무 잎과 껍질 추출물의 총 플라보노이드 함량}

두충나무 잎과 껍질 추출물의 총 플라보노이드 함량은 Davis의 방법을 변형하여 측정하였다[21]. 두충나무 잎과 껍질 추출물 $1.0 \mathrm{~mL}$ 에 diethyleneglycol $2.0 \mathrm{~mL}$ 와 $1 \mathrm{~N}$ sodium hydroxide 용 액 $0.02 \mathrm{~mL}$ 를 순차적으로 넣고 $37^{\circ} \mathrm{C}$ 에서 1 시간 놓아둔 후 420 $\mathrm{nm}$ 에서 흡광도를 측정하였다. 총 플라보노이드 함량은 $\mu \mathrm{g}$ quercetin 당량 $(\mathrm{QE}) / \mathrm{mg}$-추출물로 나타내었다.

\section{두충나무 잎과 껍질 추출물의 라디칼 소거활성}

두충나무 잎과 껍질 추출물의 $\mathrm{ABTS}$ 양이온라디칼 소거활성은 $\mathrm{Re}$ 등의 방법을 변형하여 측정하였다[22]. $7.5 \mathrm{mM} \mathrm{ABTS}$ 와 2.5 $\mathrm{mM}$ potassium persulfate가 같이 들어있는 ABTS 용액을 만들 어 암소에서 15 시간 동안 놓아둔 후 $414 \mathrm{~nm}$ 의 흡광도가 $1.5 \pm 0.2$ 가 되도록 희석하였다. 각각 농도별로 준비된 두충나무 잎과 껍질 추출물 $0.2 \mathrm{~mL}$ 에 $\mathrm{ABTS}$ 용액 $3 \mathrm{~mL}$ 를 넣고 실온에 서 90 분 동안 반응시킨 후 $414 \mathrm{~nm}$ 에서 흡광도를 측정하였다.

두충나무 잎과 껍질 추출물의 DPPH 유리라디칼 소거활성은 Blois의 방법을 변형하여 측정하였다[23]. 각각 농도별로 준비된 두충나무 잎과 껍질 추출물 $0.2 \mathrm{~mL}$ 에 $0.2 \mathrm{mM} \mathrm{DPPH}$ 용액 0.8 $\mathrm{mL}$ 를 넣고 실온에서 30 분 동안 반응시킨 후 $525 \mathrm{~nm}$ 에서의 흡 광도를 측정하였다. 양이온라디칼과 유리라디칼에 대한 소거활 성 $(\%)$ 은 $[1-($ 시료첨가군/무첨가군 $)] \times 100$ 으로 계산하였고, 대조물 질인 L-ascorbic acid와 비교하였다.

\section{두충나무 잎과 껍질 추출물의 환원력}

두충나무 잎과 껍질 추출물의 환원력은 $\mathrm{Oyaizu}$ 의 방법을 변형 하여 측정하였다[24]. 각각 농도별로 준비된 두충나무 잎과 껍 질 추출물 $3.0 \mathrm{~mL}$ 에 $0.2 \mathrm{M}$ 인산 완충용액 $(\mathrm{pH} \quad 6.86) 3.0 \mathrm{~mL}$ 와 $1 \%$ potassium ferricyanide (III) 용액 $3.0 \mathrm{~mL}$ 를 순차적으로 넣 고 $50{ }^{\circ} \mathrm{C}$ 에서 20 분 동안 반응시킨 후 $10 \%$ trichloroacetic acid $3.0 \mathrm{~mL}$ 를 처리하여 5 분 동안 원심분리 $(3,000 \times \mathrm{g})$ 하였다. 상등액 $2.0 \mathrm{~mL}$ 을 얻어 증류수 $2.0 \mathrm{~mL}$ 와 $0.1 \%$ ferric chloride 용액 $0.5 \mathrm{~mL}$ 를 넣은 후 $700 \mathrm{~nm}$ 에서 흡광도를 측정하여 대조물질인 L-ascorbic acid와 비교하였다.

\section{두충나무 잎과 껍질 추출물의 아질산염 소거활성}

두충나무 잎과 껍질 추출물의 아질산염 소거활성은 Gray와 Dugan의 방법을 변형하여 측정하였다[25]. 각각 농도별로 준비 된 두충나무 잎과 껍질 추출물 $0.5 \mathrm{~mL}$ 에 $0.2 \mathrm{M}$ citrate 완충용 액(pH 1.2) $4.0 \mathrm{~mL}$ 와 $1 \mathrm{mM}$ sodium nitrite 용액 $0.5 \mathrm{~mL}$ 를 넣 고 $37^{\circ} \mathrm{C}$ 에서 1 시간 동안 반응시켰다. 반응액 $1.0 \mathrm{~mL}$ 를 취하여 $2 \%$ acetic acid 용액 $3.0 \mathrm{~mL}$ 와 Griess 시약 $0.4 \mathrm{~mL}$ 를 순차적으 로 첨가하여 실온에서 15 분간 정치시킨 후 $520 \mathrm{~nm}$ 에서 흡광도 를 측정하였다. 소거활성 $(\%)$ 은 $[1-$ (시료첨가군/무첨가군) $] \times 100$ 으 로 계산하였고, 대조물질인 L-ascorbic acid와 비교하였다. 


\section{두충나무 잎과 껍질 추출물의 지질과산화 억제활성}

두충나무 잎과 껍질 추출물의 지질과산화 억제활성은 Nakatani 와 Kikuzaki의 방법을 변형하여 측정하였다[26]. 각각 농도별로 준비된 두충나무 잎과 껍질 추출물 $1.0 \mathrm{~mL}$ 에 $50 \mathrm{mM}$ 인산 완 충용액(pH 7.0) $4.0 \mathrm{~mL}$ 와 $2.5 \mathrm{mg} / \mathrm{mL}$ 의 linoleic acid 용액 2.0 $\mathrm{mL}$ 를 혼합하여 $45^{\circ} \mathrm{C}$ 에서 72 시간 동안 반응시켰다. 24 시간 마 다 각각의 반응액을 $0.1 \mathrm{~mL}$ 씩 채취하여 $75 \%$ 에탄올 용액 4.7 $\mathrm{mL}$ 과 $30 \%$ ammonium thiocyanate 용액 $0.1 \mathrm{~mL}$ 를 순차적으로 넣고 실온에서 5 분 동안 정치시킨 후 $20 \mathrm{mM}$ ferrous chloride 용액 $0.1 \mathrm{~mL}$ 를 넣고 $500 \mathrm{~nm}$ 에서 흡광도를 측정하였다. 지질과 산화도는 흡광도로 나타내었고, 72시간 후의 지질과산화 억제 활성 $(\%)$ 은 $[1-($ 시료첨가군/무첨가군 $)] \times 100$ 으로 계산하였다.

\section{결과 및 고찰}

두충나무 잎과 껍질 추출물의 총 폴리페놀 및 플라보노이드 함량 물과 에탄올의 혼합용액을 추출용매로 사용하여 두충나무 잎과 껍질의 추출 시 $50 \%(\mathrm{v} / \mathrm{v})$ 에탄올 추출물에서 폴리페놀 농도 및 유리라디칼 소거활성이 가장 높게 나타나서 두충나무 잎과 껍질의 추출용매로 $50 \%$ 에탄올 용액을 선정하였다. Table 1에 서 보듯이 두충나무 잎과 껍질의 $50 \%$ 에탄올 추출물의 수율은 각각 $8.1 \pm 0.31$ 과 $17.4 \pm 0.89 \%$ 로 나타났다. 두충나무 잎과 껍질 을 물로 추출하였을 때 잎의 수율은 $26.3 \%$, 껍질의 수율은 $13.2 \%$ 으로 나타난 기존의 보고[3]에 비해 두충나무 잎과 껍질 의 $50 \%$ 에탄올 추출물의 수율은 낮게 나타났다. 대부분의 경 우 식물 소재를 에탄올로 추출하였을 때 물 추출보다 수율이
낮게 나타나는데 이는 추출 용매의 에탄올 함량이 증가할수록 극성이 감소하게 되어 생체에 다량 함유되어 있는 당류, 아미 노산, 무기질, 단백질 및 핵산 등의 극성 물질들이 잘 용출되지 않아 수율이 낮아지는 것이다[10,27-29]. 두충나무 잎과 껍질의 $50 \%$ 에탄올 추출물의 총 폴리페놀 함량은 추출물 $\mathrm{mg}$ 당 각각 $64.1 \pm 3.35$ 및 $42.4 \pm 2.38 \mu \mathrm{g} \mathrm{GAE}$ 로 나타나 잎 추출물의 폴리페 놀 함량이 높았다(Table 1). 두충나무 잎과 껍질의 $50 \%$ 에탄올 추출물의 총 플라보노이드 함량은 추출물 $\mathrm{mg}$ 당 각각 $24.0 \pm 3.15$ 및 $36.7 \pm 3.18 \mu \mathrm{g} \mathrm{QE}$ 로 나타나 껍질 추출물의 플라보노이드 함 량이 높았다(Table 1).

식물체의 대표적 생리활성 물질인 폴리페놀 화합물은 페놀산 류, 플라보노이드류, stilbene류, coumarin류, 리그닌류 및 탄닌 류로 분류되며 그 구조의 페놀성 $\mathrm{OH}$ 기가 항산화 활성의 근원 으로 알려져 있다[30]. 또한 폴리페놀 화합물의 함량과 항산화 활성 간의 상관 관계가 있음이 보고된 바 있다[31]. 계절별로 수확한 두충나무 잎의 물 추출물의 폴리페놀 함량은 $75.81 \pm 10.0$ $\mu \mathrm{g} / \mathrm{mg}$ 으로, 플라보노이드 함량은 $9.52 \pm 1.3 \mu \mathrm{g} / \mathrm{mg}$ 으로 나타나 [32], 본 연구의 두충나무 잎의 $50 \%$ 에탄올 추출물과 다소 차 이가 있는데 이는 추출용매의 극성 차이에 기인한 것이다. 또 한 폴리페놀 함량의 경우, 쑥의 메탄올 추출물의 $55.6 \mu \mathrm{g} / \mathrm{mg}$ [33], 녹차 잎의 물 추출물의 $85.6 \mu \mathrm{g} / \mathrm{mg}$ [34], 홍차의 물 추출 물의 $72.03 \mu \mathrm{g} / \mathrm{mg}$ [34], 고구마 잎의 $80 \%$ 에탄올 추출물의 $85.1 \mu \mathrm{g} / \mathrm{mg}$ [35]과 비교하였을 때, 두충나무 잎의 $50 \%$ 에탄올 추출물의 폴리페놀 함량은 비슷한 수준이었으나 껍질 추출물의 폴리페놀 함량은 상대적으로 낮은 편이었다. 두충나무 잎과 껍 질의 $50 \%$ 에탄올 추출물의 플라보노이드 함량의 경우, 섬고사 리 잎, 눈개승마 잎 및 물엉겅퀴 잎의 $80 \%$ 메탄올 추출물의 각

Table 1 Yield, polyphenol and flavonoid contents of 50\% ethanolic extract of Eucommia ulmoides Oliver leaf and bark

\begin{tabular}{cccccc}
\hline \hline \multicolumn{2}{c}{ Yield (\%) } & \multicolumn{2}{c}{ Polyphenol content ${ }^{2)}(\mu \mathrm{g} \mathrm{GAE} / \mathrm{mg})$} & \multicolumn{2}{c}{ Flavonoid content ${ }^{3)}(\mu \mathrm{g} \mathrm{QE} / \mathrm{mg})$} \\
\hline Leaf extract & Bark extract & Leaf extract & Bark extract & Leaf extract & Bark extract \\
\hline $8.1 \pm 0.31^{1)}$ & $17.4 \pm 0.89^{1)}$ & $64.1 \pm 3.35^{1)}$ & $42.4 \pm 2.38^{1)}$ & $24.0 \pm 3.15^{1)}$ & $36.7 \pm 3.18^{1)}$ \\
\hline
\end{tabular}

${ }^{1)}$ Data represent means and SD of triplicate measurements

${ }^{2)}$ Polyphenol contents are expressed as $\mu \mathrm{g}$ gallic acid equivalents (GAE)/mg-extract

${ }^{3)}$ Flavonoid contents are expressed as $\mu \mathrm{g}$ quercetin equivalents $(\mathrm{QE}) / \mathrm{mg}$-extract
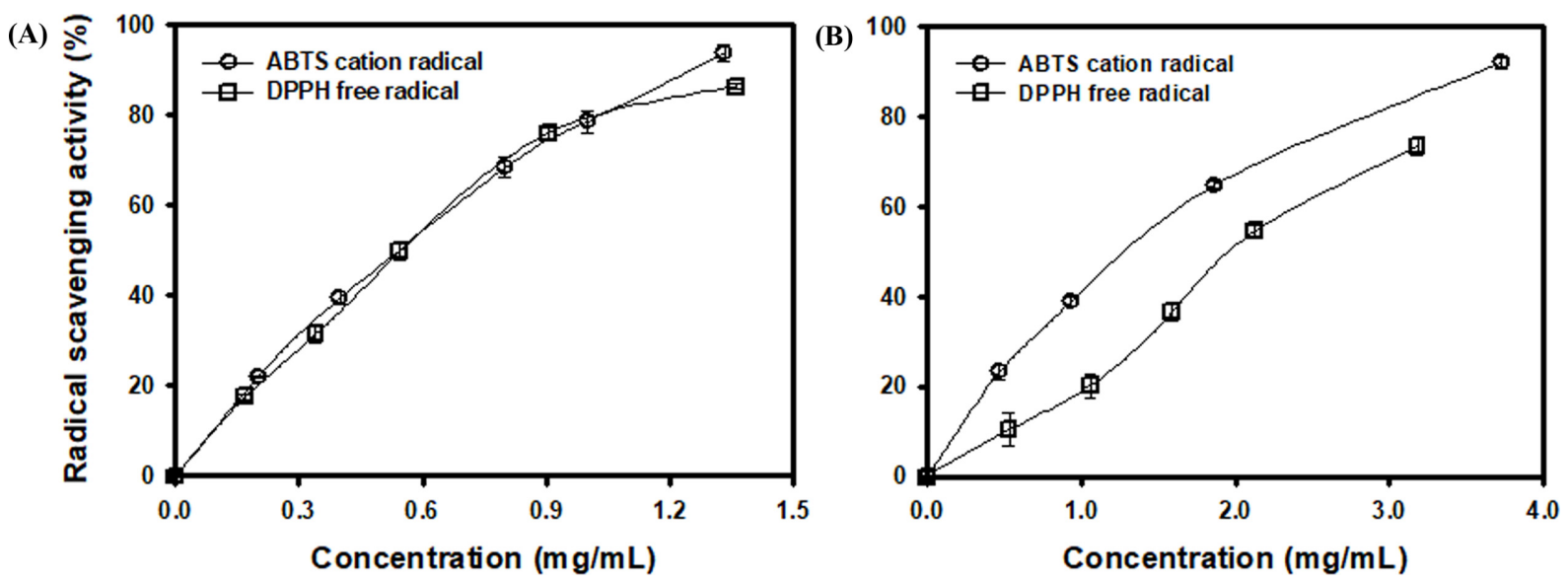

Fig. 1 ABTS cation radical scavenging and DPPH free radical scavenging activities of 50\% ethanolic extract of Eucommia ulmoides Oliver leaf (A) and bark (B). Data were means and SD of triplicate measurements 
Table 2 Antioxidative effects of 50\% ethanolic extract of Eucommia ulmoides Oliver leaf and bark

\begin{tabular}{|c|c|c|c|}
\hline \multirow{2}{*}{ Antioxidative effects } & \multicolumn{3}{|c|}{$\mathrm{EC}_{50}$ values $^{1)}(\mu \mathrm{g} / \mathrm{mL})$} \\
\hline & Leaf extract & Bark extract & L-ascorbic acid ${ }^{2)}$ \\
\hline Cation radical scavenging activity ${ }^{3)}$ & $560.6 \pm 17.65$ & $1,357.4 \pm 8.45$ & $77.8 \pm 1.76$ \\
\hline Free radical scavenging activity ${ }^{3)}$ & $574.2 \pm 14.70$ & $2,103.1 \pm 108.59$ & $45.3 \pm 4.37$ \\
\hline Ferric reducing antioxidant power ${ }^{4)}$ & $319.9 \pm 13.42$ & $705.9 \pm 26.08$ & $39.2 \pm 1.84$ \\
\hline Nitrite scavenging activity ${ }^{4}$ & $2,329.2 \pm 35.11$ & $5,467.6 \pm 243.92$ & $349.2 \pm 11.77$ \\
\hline
\end{tabular}

${ }^{1)}$ Data represent means and SD of triplicate measurements

${ }^{2)} \mathrm{L}$-ascorbic acid was used as a positive control

${ }^{3)} \mathrm{EC}_{50}$ values for radicals scavenging are expressed as the concentrations at which $50 \%$ of ABTS cation and DPPH free radicals were scavenged, respectively

${ }^{4)} \mathrm{EC}_{50}$ values for ferric reducing antioxidant power and nitrite scavenging are expressed as the concentrations at which the absorbance was 0.500 and at which $50 \%$ of nitrite were scavenged, respectively

(A)

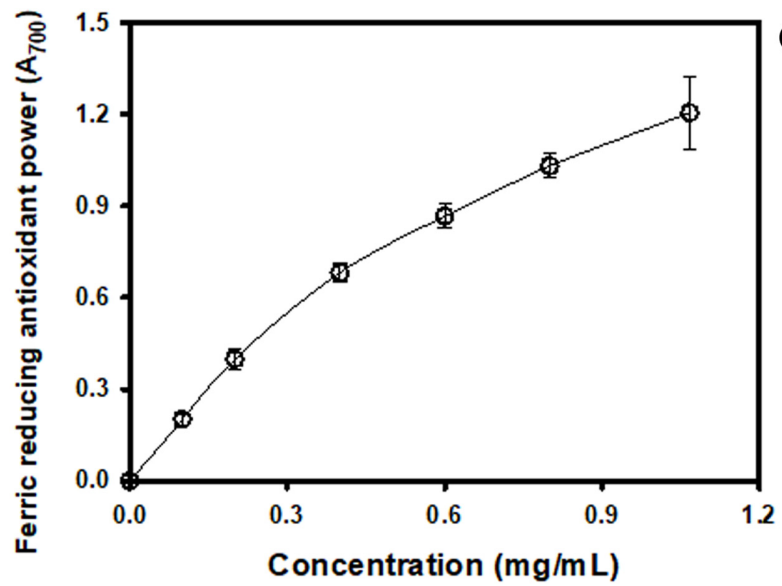

(B)

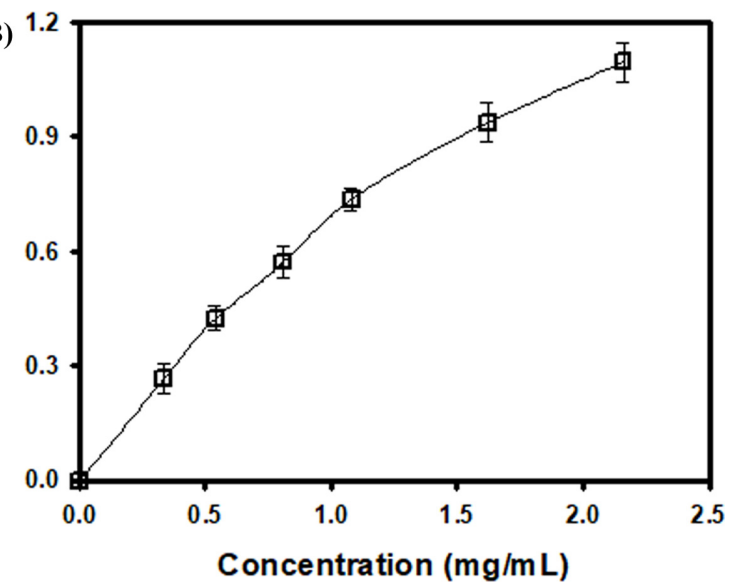

Fig. 2 Ferric reducing antioxidant power of 50\% ethanolic extract of Eucommia ulmoides Oliver leaf (A) and bark (B). Data were means and SD of triplicate measurements

각 $16.8,16.5$ 및 $13.3 \mu \mathrm{g} / \mathrm{mg}$ 보다는 높았고[36], 백연수 잎의 $50 \%$ 에탄올 추출물의 $105.2 \mu \mathrm{g} / \mathrm{mg}$ [29] 보다는 낮게 나타났다.

\section{두충나무 잎과 껍질 추출물의 라디칼 소거활성}

두충나무 잎과 껍질의 $50 \%$ 에탄올 추출물의 $\mathrm{ABTS}$ 양이온라 디칼 소거활성은 농도에 비례하여 증가하였다(Fig. 1). ABTS 양 이온라디칼을 $50 \%$ 소거하는 농도인 $\mathrm{EC}_{50}$ 값은 잎 추출물은 $560.6 \pm 17.65 \mu \mathrm{g} / \mathrm{mL}$ 이었고, 껍질 추출물은 $1,357.4 \pm 8.45 \mu \mathrm{g} / \mathrm{mL}$ 로 나타나 잎 추출물의 양이온라디칼 소거활성이 껍질 추출물에 비 해 2배 정도 우수하였다(Table 2). 두충나무 잎 추출물의 양이 온라디칼 소거활성은 대조물질로 사용된 L-ascorbic acid의 $\mathrm{EC}_{50}$ 값인 $77.8 \pm 1.76 \mu \mathrm{g} / \mathrm{mL}$ 에 비해 7.2배 높았으나(Table 2), 추출물 의 구성이 단일 성분이 아닌 다양한 성분들의 혼합물인 것을 고려하면 두충나무 잎 추출물의 $\mathrm{ABTS}$ 양이온라디칼 소거활성 은 우수한 것으로 여겨진다. 두충나무 잎의 $50 \%$ 에탄올 추출 물의 $\mathrm{ABTS}$ 소거에 대한 $\mathrm{EC}_{50}$ 값은 백연수 잎의 $50 \%$ 에탄올 추출물의 $667.2 \mu \mathrm{g} / \mathrm{mL}$ [29] 보다는 낮았으나, Napier grass의 $50 \%$ 에탄올 추출물의 $350.0 \mu \mathrm{g} / \mathrm{mL}$ [37], 홍차박 $30 \%$ 에탄올 추출물의 $141.8 \mu \mathrm{g} / \mathrm{mL}$ [27], 물엉겅퀴 잎과 섬고사리 잎의 $70 \%$ 메탄올 추출물의 40.7 및 $92.6 \mu \mathrm{g} / \mathrm{mL}$ [36] 보다는 높게 나타났다.

두충나무 잎과 껍질의 $50 \%$ 에탄올 추출물의 $\mathrm{DPPH}$ 유리라 디칼 소거활성도 농도에 비례하여 증가하였다(Fig. 1). DPPH 유
리라디칼을 $50 \%$ 소거하는 농도인 $\mathrm{EC}_{50}$ 값은 잎 추출물의 경우 $574.2 \pm 14.70 \mu \mathrm{g} / \mathrm{mL}$ 로 $\mathrm{ABTS}$ 양이온라디칼 소거활성과 비슷한 수준이었으나, 껍질 추출물은 $2,103.1 \pm 108.59 \mu \mathrm{g} / \mathrm{mL}$ 로 나타나 양이온라디칼 소거활성에 비해서는 활성이 낮았다(Table 2). 두 충나무 잎과 껍질의 $50 \%$ 에탄올 추출물의 $\mathrm{DPPH}$ 소거에 대한 $\mathrm{EC}_{50}$ 값은 두충나무 잎과 껍질의 물 추출물의 $\mathrm{EC}_{50}$ 값인 274.0 및 $955.0 \mu \mathrm{g} / \mathrm{mL}$ [3]에 비해 높게 나타났다. 또한 두충나무 잎 의 $50 \%$ 에탄올 추출물의 $\mathrm{EC}_{50}$ 값은 두충나무 잎의 아세톤 추출 물의 $2,077.8 \mu \mathrm{g} / \mathrm{mL}$ [10] 및 Napier grass의 $50 \%$ 에탄올 추출 물의 $1,930.0 \mu \mathrm{g} / \mathrm{mL}$ [37] 보다는 크게 낮았으나, 백연수 잎의 $50 \%$ 에탄올 추출물의 $133.5 \mu \mathrm{g} / \mathrm{mL}$ [29], 홍차박의 $30 \%$ 에탄올 추출물의 $108.1 \mu \mathrm{g} / \mathrm{mL}$ [27], 녹차의 물 추출물의 $25.2 \mu \mathrm{g} / \mathrm{mL}$ [38], 고려엉겅퀴 잎의 에탄올 추출물의 $111.2 \mu \mathrm{g} / \mathrm{mL}$ [39] 및 고 구마 잎의 $80 \%$ 에탄올 추출물의 $109.0 \mu \mathrm{g} / \mathrm{mL}$ [35] 보다는 높 게 나타났다.

\section{두충나무 잎과 껍질 추출물의 환원력}

두충나무 잎과 껍질의 $50 \%$ 에탄올 추출물의 $\mathrm{Fe}^{3+}$ 이온에 대한 환원력 역시 농도에 비례하여 증가하였다(Fig. 2). 환원력의 흡 광도가 0.5 에 도달하는데 필요한 농도인 $\mathrm{EC}_{50}$ 값은 잎 추출물은 $319.9 \pm 13.42 \mu \mathrm{g} / \mathrm{mL}$ 이었고, 껍질 추출물은 $705.9 \pm 26.08 \mu \mathrm{g} / \mathrm{mL}$ 로 나타나 잎 추출물의 환원력이 껍질 추출물에 비해 2 배 이상 우 

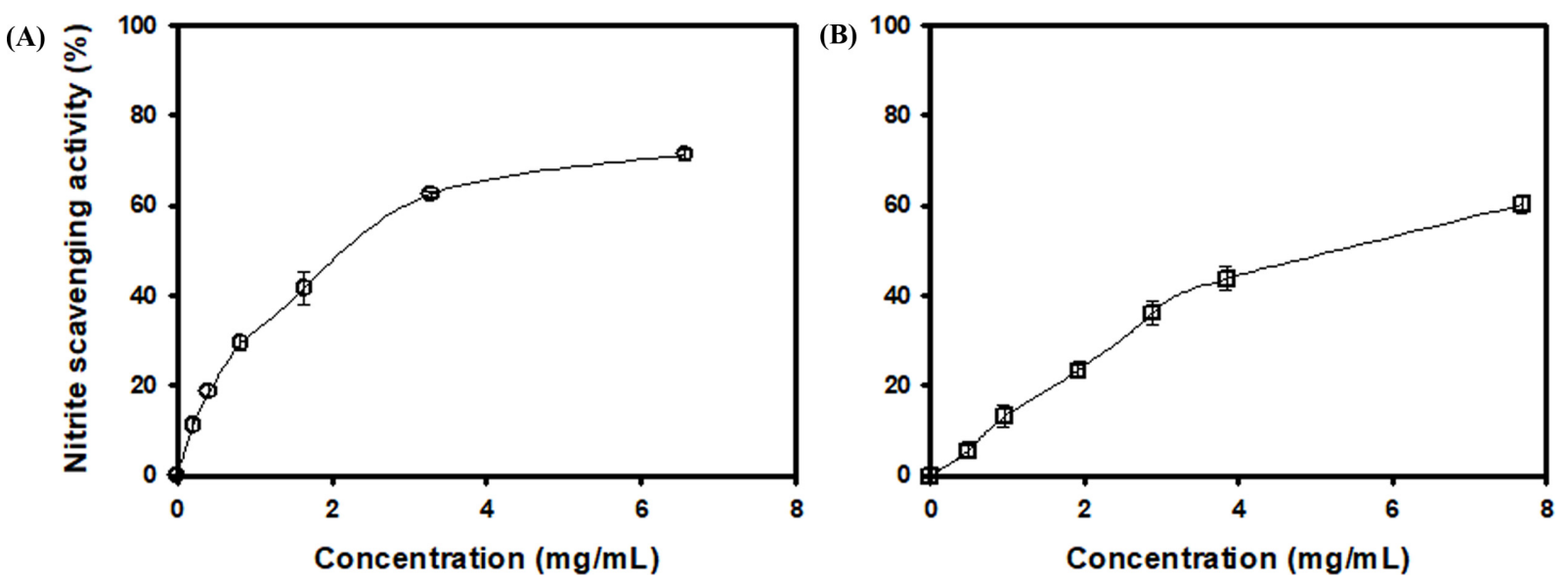

Fig. 3 Nitrite scavenging activity of 50\% ethanolic extract of Eucommia ulmoides Oliver leaf (A) and bark (B). Data were means and SD of triplicate measurements

수하였다(Table 2). 두충나무 잎 추출물의 환원력은 대조물질로 사용된 L-ascorbic acid의 $\mathrm{EC}_{50}$ 값인 $39.2 \pm 1.84 \mu \mathrm{g} / \mathrm{mL}$ 에 비해 8.2배 높았으나(Table 2), 그 추출물이 여러 다양한 성분들의 혼 합물인 것을 고려하면 두충나무 잎 추출물의 환원력은 우수한 것으로 여겨진다. 두충나무 잎의 $50 \%$ 에탄올 추출물의 환원력 ( $\mathrm{EC}_{50}$ 값)은 두충나무 잎의 아세톤 추출물의 $275.8 \mu \mathrm{g} / \mathrm{mL}$ [10], 백연수 잎의 $50 \%$ 에탄올 추출물의 $250.0 \mu \mathrm{g} / \mathrm{mL}$ [29] 및 자색 고구마 뿌리의 $70 \%$ 에탄올 추출물의 $236.0 \mu \mathrm{g} / \mathrm{mL}$ [40]와 비슷 한 수준이었고, Napier grass의 $50 \%$ 에탄올 추출물의 $840.0 \mu \mathrm{g} /$ $\mathrm{mL}$ [37], 복분자와 오디 열매의 아세톤 추출물의 871.0 및 $746.0 \mu \mathrm{g} / \mathrm{mL}$ [41] 보다는 낮은 값을 나타내어 두충나무 잎의 $50 \%$ 에탄올 추출물의 환원력은 우수한 수준으로 볼 수 있다.

\section{두충나무 잎과 껍질 추출물의 아질산염 소거활성}

두충나무 잎과 껍질의 $50 \%$ 에탄올 추출물의 아질산염 소거활 성도 라디칼 소거활성 및 환원력과 동일하게 농도에 비례하여 증가하였다(Fig. 3). 아질산염은 위산의 산성 조건에서 아민류와 반응하여 발암성을 가진 nitrosamine을 생성하는데 항산화 물질 은 이러한 아질산염을 효과적으로 소거하는 것으로 알려져있다 [42]. 아질산염을 $50 \%$ 소거하는 농도인 $\mathrm{EC}_{50}$ 값은 잎 추출물은 $2,329.2 \pm 35.11 \mu \mathrm{g} / \mathrm{mL}$ 이었고, 껍질 추출물은 $5,467.6 \pm 243.92 \mu \mathrm{g} /$ $\mathrm{mL}$ 로 나타나 잎 추출물의 아질산염 소거활성이 껍질 추출물에 비해 2.3배 우수하였다(Table 2). 두충나무 잎 추출물의 아질산 염 소거활성은 대조물질로 사용된 L-ascorbic acid의 $\mathrm{EC}_{50}$ 값인 $349.2 \pm 11.77 \mu \mathrm{g} / \mathrm{mL}$ 에 비해 6.7배 높았으나(Table 2), 역시 추출 물이 여러 다양한 성분들의 혼합물인 것을 고려하면 두충나무 잎 추출물의 아질산염 소거활성은 우수하다고 볼 수 있다. 두 충나무 잎의 $50 \%$ 에탄올 추출물의 $\mathrm{EC}_{50}$ 값은 백연수 잎의 $50 \%$ 에탄올 추출물의 $2,582.9 \mu \mathrm{g} / \mathrm{mL}$ [29]과는 비슷한 수준이었고, Napier grass의 $50 \%$ 에탄올 추출물의 $1,470.0 \mu \mathrm{g} / \mathrm{mL}$ [37] 및 홍차박의 $30 \%$ 에탄올 추출물의 $397.2 \mu \mathrm{g} / \mathrm{mL}$ [27] 보다는 높게 나타났다. 또한 쑥의 $70 \%$ 에탄올 추출물은 $1.0 \mathrm{mg} / \mathrm{mL}$ 의 농도 에서 아질산염을 $41 \%$ 소거한다고 보고된 바 있다[43].

\section{두충나무 잎과 껍질 추출물의 지질과산화 억제활성}

두충나무 잎과 껍질의 $50 \%$ 에탄올 추출물은 불포화 지방산인 linoleic acid의 산화를 농도에 비례하여 억제하였다(Fig. 4). 시 간에 따라 linoleic acid의 과산화물이 증가하는데, 두충나무 잎 과 껍질 추출물의 첨가는 농도의존적으로 과산화물의 생성을 억 제하였다(Fig. 4). Linoleic acid 산화반응의 72시간 후에 두충나 무 잎 추출물은 $74.8 \mu \mathrm{g} / \mathrm{mL}$ 의 농도에서 과산화물의 생성을 $70.0 \%$ 억제한 반면, 껍질 추출물은 $177.2 \mu \mathrm{g} / \mathrm{mL}$ 의 농도에서 과 산화물의 생성을 $79.1 \%$ 억제하는 것으로 나타나 잎 추출물의 지질과산화 억제활성이 우수하였다. 이는 두충나무 잎과 껍질의 물 추출물이 $200 \mu \mathrm{g} / \mathrm{mL}$ 의 농도에서 linoleic acid의 과산화를 각각 99.9 및 $77.2 \%$ 억제한다는 보고[18]와도 상당히 일치하였 다. 또한 백연수 잎의 $50 \%$ 에탄올 추출물은 $555.0 \mu \mathrm{g} / \mathrm{mL}$ 의 농 도에서 지질과산화를 $54.1 \%$ 억제[29], Napier grass의 $30 \%$ 에 탄올 추출물은 $85.0 \mu \mathrm{g} / \mathrm{mL}$ 의 농도에서 $74.6 \%$ 억제[37], 스타구 스베리(Phyllanthus acidus) 잎의 물 추출물은 $716.3 \mu \mathrm{g} / \mathrm{mL}$ 의 농도에서 $50 \%$ 억제[44]. 고사리 잎과 물엉겅퀴 잎의 $70 \%$ 메탄 올 추출물은 $100.0 \mu \mathrm{g} / \mathrm{mL}$ 의 농도에서 $90 \%$ 이상 억제[36]한다 는 기존의 연구에 비해서도 두충나무 잎과 껍질의 $50 \%$ 에탄올 추출물의 지질과산화 억제활성은 우수하다고 여겨진다.

기존의 연구에서는 두충나무의 잎과 껍질을 물로 추출하여 활성산소 소거능, linoleic acid 과산화 억제 활성[5,18] 및 $\mathrm{DNA}$ 와 같은 생체분자에 대한 산화 억제 효과를 보고한 바 있 다[19]. 본 연구에서는 두충나무의 잎과 껍질을 물 대신 $50 \%$ 에탄올로 추출하여 양이온라디칼과 유리라디칼 소거활성, 환원 력, 아질산염 소거활성, 지질과산화 억제 활성을 비교함으로써 기존의 연구 $[5,18,19]$ 에 더하여 두충나무 잎과 껍질의 다양한 항 산화 효과를 확인하였다.

이상의 결과에서 두충나무 잎과 껍질의 $50 \%$ 에탄올 추출물 은 폴리페놀과 플라보노이드 화합물을 다량 함유하고 있고, 양 이온라디칼, 유리라디칼과 아질산염을 소거하고, $\mathrm{Fe}^{3+}$ 이온을 환 원시키며, 지질과산화를 억제하는 항산화 활성을 보유하고 있었 다. 두충나무 껍질보다 잎 추출물의 항산화 활성이 우수한 것 

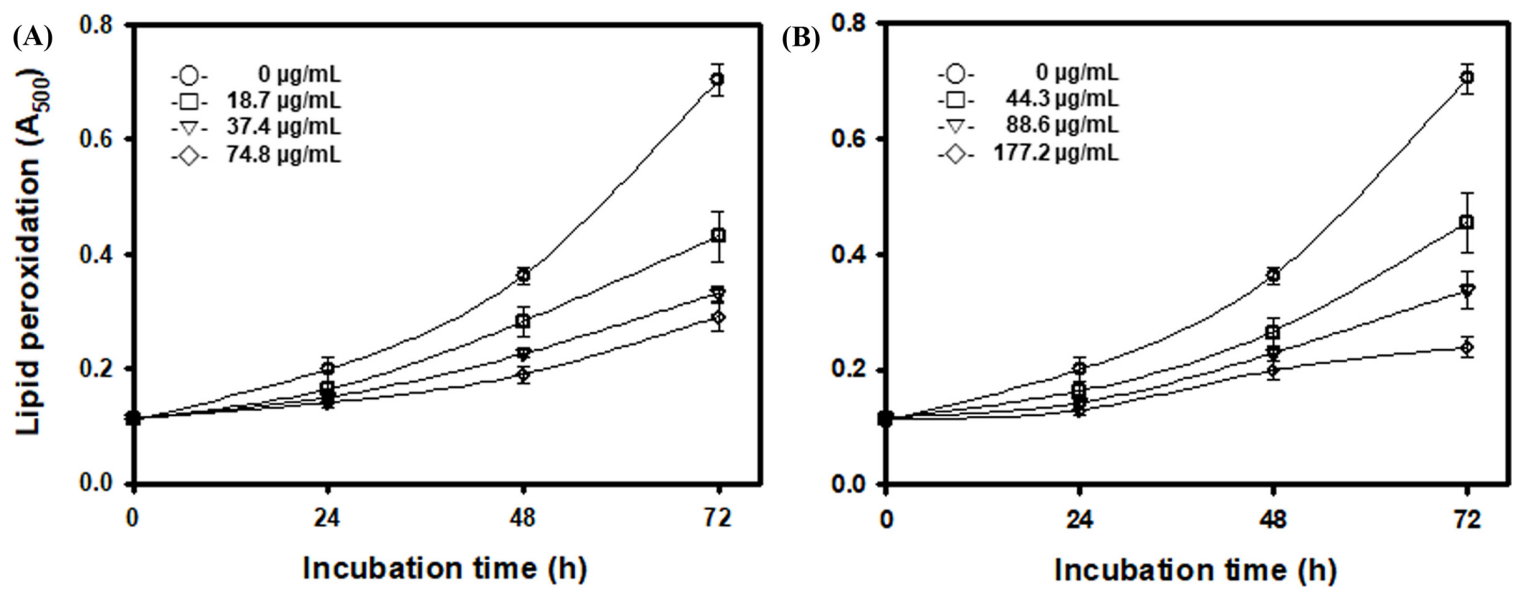

Fig. 4 Lipid peroxidation inhibitory activity of 50\% ethanolic extract of Eucommia ulmoides Oliver leaf (A) and bark (B) as a function of incubation time. Data were means and SD of triplicate measurements

으로 나타나 두충나무 잎의 $50 \%$ 에탄올 추출물은 천연의 항산 화 생리활성 소재로서 활용 가능성이 높다고 여겨진다.

\section{초 록}

두충나무(Du-zhong, Eucommia ulmoides Oliver)의 잎과 껍질로 부터 얻어진 $50 \%$ 에탄올 추출물의 항산화 활성을 확인하였다. 두충나무 잎과 껍질 추출물의 수율은 각각 $8.1 \pm 0.31$ 과 $17.4 \pm 0.89 \%$, 총 폴리페놀 함량은 각각 $64.1 \pm 3.35$ 와 $42.4 \pm 2.38 \mu \mathrm{g} \mathrm{GAE} / \mathrm{mg}$, 총 플라보노이드 함량은 각각 $24.0 \pm 3.15$ 와 $36.7 \pm 3.18 \mu \mathrm{g} \mathrm{QE} /$ $\mathrm{mg}$ 으로 나타났다. 두충나무 잎과 껍질 추출물은 농도에 비례하 여 양이온라디칼, 유리라디칼과 아질산염을 소거하였고, 환원력 을 증가시켰으며 지질과산화를 억제하였다. 두충나무 잎과 껍질 추출물의 $\mathrm{ABTS}$ 양이온라디칼 소거에 대한 $\mathrm{EC}_{50}$ 값은 각각 $560.6 \pm 17.65$ 와 $1,357.4 \pm 8.45 \mu \mathrm{g} / \mathrm{mL}$ 이었고, $\mathrm{DPPH}$ 유리라디칼 소 거에 대한 $\mathrm{EC}_{50}$ 값은 각각 $574.2 \pm 14.70$ 과 $2,103.1 \pm 108.59 \mu \mathrm{g}$ $\mathrm{mL}$ 로 나타났다. 또한 두충나무 잎과 껍질 추출물의 환원력에 대한 $\mathrm{EC}_{50}$ 값은 각각 $319.9 \pm 13.42$ 와 $705.9 \pm 26.08 \mu \mathrm{g} / \mathrm{mL}$ 였고, 아 질산염 소거에 대한 $\mathrm{EC}_{50}$ 값은 각각 2,329.2 \pm 35.11 과 5,467.6 \pm 243.92 $\mu \mathrm{g} / \mathrm{mL}$ 로 나타났다. 두충나무 잎 추출물은 $74.8 \mu \mathrm{g} / \mathrm{mL}$ 의 농도에 서, 껍질 추출물은 $177.2 \mu \mathrm{g} / \mathrm{mL}$ 의 농도에서 linoleic acid의 과 산화를 각각 70.0 및 $79.1 \%$ 억제하였다. 두충나무 잎 추출물은 껍질 추출물에 비해 높은 항산화 활성을 보유하고 있었다.

Keywords 두충나무(Eucommia ulmoides Oliver) - 에탄올 추출 물 · 폴리페놀 · 플라보노이드 · 항산화 활성

\section{References}

1. Kwan CY, Chen CX, Deyama T, Nishibe S (2003) Endotheliumdependent vasorelaxant effects of the aqueous extracts of the Eucommia ulmoides Oliv. leaf and bark: implications on their antihypertensive action. Vascul Pharmacol 40: 229-235

2. Kawasaki T, Uezono K, Nakazawa Y (2000) Antihypertensive mechanism of food for specified health use: "Eucommia leaf glycoside" and its clinical application. J Health Sci 22: 29-36

3. Zhang Q, Su YQ, Yang FX, Peng JN, Li XH, Sun RC (2007) Antioxidative activity of water extracts from leaf, male flower, raw cortex and fruit of Eucommia ulmoides Oliv. Forest Products J 57: 74-78

4. Lee MK, Kim MJ, Cho SY, Park SA, Park KK, Jung UJ, Park HM, Choi MS (2005) Hypoglycemic effect of Du-zhong (Eucommia ulmoides Oliv.) leaves in streptozotocin-induced diabetic rats. Diabetes Res Clin Pract 67: 22-28

5. Yen GC, Hsieh CL (2000) Reactive oxygen species scavenging activity of Du-Zhong (Eucommia ulmoides Oliv.) and its active compounds. J Agric Food Chem 48: 3431-3436

6. Yang J, Kato K, Noguchi K, Dairaku N, Koike T, Iijima K, Imatani A, Sekine H, Ohara S, Sasano H, Shimosegawa T (2003) Tochu (Eucommia ulmoides) leaf extract prevents ammonia and vitamin $\mathrm{C}$ deficiency induced gastric mucosal injury. Life Sci 73: 3245-3256

7. Hirata T, Kobayashi T, Wada A, Ueda T, Fujikawa T, Miyashita H, Ikeda T, Tsukamoto S, Nohara T (2011) Anti-obesity compounds in green leaves of Eucommia ulmoides. Bioorg Med Chem Lett 21: 1786-1791

8. Choi MS, Jung UJ, Kim HJ, Do GM, Jeon SM, Kim MJ, Lee MK (2008) Du-zhong (Eucommia ulmoides Oliver) leaf extract mediates hypolipidemic action in hamsters fed a high-fat diet. Am J Chin Med 36: 81-93

9. Park SA, Choi MS, Jung UJ, Kim MJ, Kim DJ, Park HM, Park YB, Lee MK (2006) Eucommia ulmoides Oliver leaf extract increases endogenous antioxidant activity in type 2 diabetic mice. J Med Food 9: 474-479

10. In MJ, Kim EJ, Kim DC (2018) In vitro anticancer and antioxidant effects of acetone extract of Eucommia ulmoides Oliver leaves. J Appl Biol Chem 61: 119-124

11. Kim BH, Park KS, Chang IM (2009) Elucidation of anti-inflammatory potencies of Eucommia ulmoides bark and Plantago asiatica seeds. J Med Food 12: 764-769

12. Tsai TH, Tsai TH, Wu WH, Tseng JTP, Tsai PJ (2010) In vitro antimicrobial and anti-inflammatory effects of herbs against Propionibacterium acnes. Food Chem 119: 964-968

13. Zhang R, Liu ZG, Li C, Hu SJ, Liu L, Wang JP, Mei QB (2009) DuZhong (Eucommia ulmoides Oliv.) cortex extract prevent OVX-induced osteoporosis in rats. Bone 45: 553-559

14. Jin CF, Li B, Lin SM, Yadav RK, Kim HR, Chae HJ (2013) Mechanism of the inhibitory effects of Eucommia ulmoides Oliv. cortex extracts (EUCE) in the $\mathrm{CCl}_{4}$-induced acute liver lipid accumulation in rats. Int $\mathrm{J}$ Endocrinol 2013: 751854

15. Kwon SH, Lee HK, Kim JA, Hong SI, Kim SY, Jo TH, Park YI, Lee 
CK, Kim YB, Lee SY, Jang CG (2011) Neuroprotective effects of Eucommia ulmoides Oliv. bark on amyloid beta(25-35)-induced learning and memory impairments in mice. Neurosci Lett 487: 123-127

16. Greenway F, Liu Z, Yu Y, Gupta A (2011) A clinical trial testing the safety and efficacy of a standardized Eucommia ulmoides Oliver bark extract to treat hypertension. Altern Med Rev 16: 338-347

17. Oshima Y, Takata S, Hikino H, Deyama Y, Kinoshita G (1988) Anticomplementary activity of the constituents of Eucommia ulmoides bark. J Ethnopharmacol 23: 159-164

18. Yen GC, Hsieh CL (1998) Antioxidant activity of extracts from Duzhong (Eucommia ulmoides) toward various lipid peroxidation models in vitro. J Agric Food Chem 46: 3952-3957

19. Hsieh CL, Yen GC (2000) Antioxidant actions of Du-zhong (Eucommia ulmoides Oliv.) toward oxidative damage in biomolecules. Life Sci 66: $1387-1400$

20. Folin O, Denis W (1912) On phosphotungstic-phosphomolybdic compounds as color reagents. J Biol Chem 12: 239-243

21. Davis WB (1947) Determination of flavanones in citrus fruits. Anal Chem 19: 476-478

22. Re R, Pellegrini N, Proteggente A, Pannala A, Yang M, Rice-Evans C (1999) Antioxidant activity applying an improved ABTS radical cation decolorization assay. Free Radical Biol Med 26: 1231-1237

23. Blois MS (1958) Antioxidant determination by the use of a stable free radical. Nature 181: 1199-1200

24. Oyaizu M (1986) Studies on product of browning reaction: antioxidative activities of products of browning reaction prepared from glucosamine. Jap J Nutr 44: 307-315

25. Gray JI, Dugan Jr LR (1975) Inhibition of N-nitrosamine formation in model food system. J Food Sci 40: 981-985

26. Nakatani N, Kikuzaki H (1987) A new antioxidative glucoside isolated from oregano (Origanum vulgare L.). Agric Biol Chem 51: 2727-2732

27. Kim DC (2019) In vitro antioxidant activity of black tea (Camellia sinensis L.) residue extract. J Appl Biol Chem 62: 281-286

28. Kim C, In MJ, Kim DC (2015) In vitro antioxidant activity of ethanol extract from Boehmeria nivea L. leaves. Food Eng Prog 19: 76-81

29. Kim DC, In MJ (2017) Antioxidative ability of ethanol extract from the leaves of Leucaena leucocephala (Lam.) de Wit. J Appl Biol Chem 60: 185-190

30. Shahidi F, Yeo JD (2018) Bioactivities of phenolics by focusing on suppression of chronic diseases: a review. Int J Mol Sci 19: 1573

31. Arnous A, Makris DP, Kefalas P (2001) Effect of principal polyphenolic components in relation to antioxidant characteristics of aged red wines. $\mathrm{J}$ Agric Food Chem 49: 5736-5742
32. Zhang Q, Su Y, Zhang J (2013) Seasonal difference in antioxidant capacity and active compounds contents of Eucommia ulmoides Oliver leaf. Molecules 18: 1857-1868

33. Lee YM, Bae JH, Jung HY, Kim JH, Park DS, Jung HY (2011) Antioxidant activity in water and methanol extracts from Korean edible wild plants. J Korean Soc Food Sci Nutr 40: 29-36

34. Jeong CH, Kang ST, Joo OS, Lee SC, Shin YH, Shim KH, Cho SH, Choi SG, Heo HJ (2009) Phenolic content, antioxidant effect and acetylcholinesterase inhibitory activity of Korean commercial green, puer, oolong, and black teas. Korean J Food Preserv 16: 230-237

35. Li M, Jang GY, Lee SH, Woo KS, Sin HM, Kim HS, Lee J, Jeong HS (2012) Chemical compositions and antioxidant activities of leaves and stalks from different sweet potato cultivars. J Korean Soc Food Sci Nutr 41: $1656-1662$

36. Lee SO, Lee HJ, Yu MH, Im HG, Lee IS (2005) Total polyphenol contents and antioxidant activities of methanol extracts from vegetables produced in Ullung Island. Korean J Food Sci Technol 37: 233-240

37. Kwon YJ, Kim DC (2019) In vitro antioxidant effect of ethanol extract from Pennisetum purpureum. J Appl Biol Chem 62: 167-172

38. Oh JH, Kim EH, Kim JL, Moon YI, Kang YH, Kang JS (2004) Study on antioxidant potency of green tea by DPPH method. J Korean Soc Food Sci Nutr 33: 1079-1084

39. Lee SH, Jin YS, Heo SI, Shim TH, Sa JH, Choi DS, Wang MH (2006) Composition analysis and antioxidative activity from different organs of Cirsium setidens Nakai. Korean J Food Sci Technol 38: 571-576

40. Kim DC, Kim C, In MJ (2015) Antioxidant activities of extracts prepared from sweet potatoes with different flesh colors. J Appl Biol Chem 58: 21-24

41. Jun HI, Kim YA, Kim YS (2014) Antioxidant activities of Rubus coreanus Miquel and Morus alba L. fruits. Korean Soc Food Sci Nutr 43: $381-388$

42. Mirvish SS (1995) Role of N-nitroso compounds (NOC) and Nnitrisation in etiology of gastric, esophageal, nasopharyngeal and bladder cancer and contribution to cancer of known exposure to NOC. Cancer Lett 93: $17-48$

43. Park CS, Kim ML (2006) Functional properties of mugwort extracts and quality characteristics of noodle added mugwort powder. Korean J Food Preserv 13: 161-167

44. Nguyen TTK, Laosinwattana C, Teerarak M, Pilasombut K (2017) Potential antioxidant and lipid peroxidation inhibition of Phyllanthus acidus leaf extract in minced pork. Asian-Australas J Anim Sci 30: $1323-1331$ 